\title{
REFLECTIONS ON RACIAL IDENTITY AND THE BLACK MOVEMENT IN THE UNITED STATES AND BRAZIL
}

\section{David Covin \\ California State University, Sacramento}

"... we shall gradually recognize that the racialization of democray is as important as the democratization of race."

Howard Winant, 1999*

\section{Introduction}

These reflections are based on a long history of study and involvement in the Black movement in the United States, on friendships with militants in the Brazilian Black movement, and on study of that movement. They arise directly from musings occasioned by comments made by an undergraduate white student in my course, Politics of the African Diaspora, and by my observation of a couple on the Avenida Sete de Setembro in Salvador, Bahia.

In a paper for my politics of the African diaspora course, one of my students made an argument which contradicted everything I knew and understood about the conditions of Afro-Brazilians in Salvador. More troubling was the reality that his analysis was sound and systematically substantiated. The essay grew out of an assignment to critique Kim Butler's book, Freedoms Given, Freedoms Won, particularly her comparative analysis of racial identity and resistance in the 
two cities of Sao Paulo and Salvador in the post abolition period.

The student's central analysis with respect to Salvador was that the percentage of Africans in the population was so high that it was literally impossible to restrict Africans solely to the most menial and degraded conditions of work. For a society to operate, tasks have to be performed, and the reality in Salvador was that some of those tasks which were not offensive had to be carried out by Black people. There was no alternative. No other persons were available in the population pool.

Because I have seen Salvador and the actual conditions experienced by most Black people there; because I am familiar with the high rates of disease, illiteracy, unemployment, incarceration, infant mortality, sexual exploitation, and social subjugation in Salvador - now, at the beginning of the 21st century - his position of what it was over 100 years ago clashed with my more informed opinion. He had, nevertheless, done an adequate job of supporting it. I asked him, therefore, to explore the question more fully in a prepared oral discussion. He did, he did a substantial job, and he came to the same conclusion.

My delayed recognition that his analysis was substantially correct alerted me to the need to keep the complexity of the Black condition always at the forefront of my thinking. While it was true that poverty, oppression, exploitation, physical degradation, illiteracy, abysmal housing, and being held in contempt by whites were the general and primary conditions of Black people in Salvador, those conditions could not characterize the Black experience because it was more complex than that. The generalization about miserable circumstances could be an important part of the characterization, but only a part. In the variations and character of the variations of Afro-Brazilian lives in Salvador lay perhaps the most critical factors for an informed analysis.

Because I turned in my final grades for that course on May 19th, 2000, and I arrived in Salvador on May 21st, 2000, the student's point was very much a part of my thoughts upon my return to Bahia.

I turn now to the couple I observed on a street corner about a week after my arrival in Salvador. They were standing, holding hands, waiting for the light to change. Both were in their early twenties. He was Black and she was white. That is not an unusual combination in Salvador. Nor is the reverse - a white man and a Black woman. In fact, because the operational definition of race in Brazil is appearance, not ancestry, it is not unusual to have brothers and sisters, some of whom are Black and others of whom are white. The Reitora (President) of the State University of Bahia, a Black woman, and the first and only Black President of any Brazilian university, invited members of the National Conference of Black Political Scientists (NCOBPS) to her house for a birthday party. The other people present were principally family members. Two-thirds were Black and one-third 
were white. To speak of racial identity in such a situation is to bring the question of race into the most intimate of human relations, the family. Nor in Salvador is this condition of a family which is at once Black and white a preserve of a single family. On the contrary, there are literally tens of thousands of families of similar description.

In the Reconcavo, the area of plantations, forests, and small towns to the south of the city of Salvador, and surrounding the bay, the Bahia de Todos os Santos, many settlements have populations that are 99\% Black. In such circumstances, when white people look for mates, their options are very much expanded if they regard Black people as prospective husbands and wives. Indeed, that is what happens. Rare is the case of a Reconcavo white person who has no Black relatives.

This is my student's point, made another way. The African presence in Bahia is so extensive that it cannot be entirely excluded from any segment of white life, including the family.

\section{Race as an Identifier of Persons}

In Salvador and in many places in Brazil, to speak of race as an identifier of persons is to give different identities to people who are closely involved with each other as neighbors, friends, workers, lovers, and relatives. If people have to choose between an abstract identity such as race and identification with human beings with whom they are intimately involved, there is little doubt about which choice they will make. This reality has profound consequences for the Black movement in Brazil.

This joining of people of different races in the most important human relationships is evermore the case in the United States. The rigid barriers which used to act as formidable obstacles to deep and sustained commitments across racial lines have weakened. Increasingly families are composed of people from more than one racial group. Again, in such circumstances, to speak of race as an identifier is to speak of persons within the social unit which is the primary source of people's identity as essentially different, antithetical, if you will.

In the U.S. this is new. In the past Tiger Woods would have had no choice about his identity. Nor would Wardell Connerly. Now they do. Today if people choose to accept a single racial identity, in many ways they alienate some of those to whom they are closest. A non-Black parent can feel very much threatened by a child, for example, choosing a racial identity entirely different from that parent's. Parents don't want to be alientated from their children. They, their spouses, and their children understand that. The children don't want to alienate their fathers or mothers and therefore may be extremely reluctant to choose a 
single racial identity.

As such trends persist in Brazil and as they increase in the United States, they reduce the number of people who experience no contradiction in self-identifying as Black. They reduce the number of potential participants in the Black movement.

This is a question worthy of analysis for movement activists in both countries. It is not going away. It is one which both movements have a responsibility to address, and to address in the most forthright and rigorous fashion. The question must not be side-stepped. It must be embraced in its full complexity.

Here is a particular role for Black intellectuals in the movement. We must take the initiative and wrestle with the difficulties. We must state our thinking unambiguously. We must do it now - before the ground is totally taken over by others. This essay is a modest effort to target some key elements in the struggle to conceive of a vital Black movement in racially complex societies.

\section{Alienation}

A key recognition to make in developing a conceptualization of the problem which is faithful to a commitment to the Black movement is that assuming a Black identity does not require one to alienate oneself from one's intimates who are not Black. Here I'm not going into the genetic evidence which renders race useless as a scientific category, nor into the characteristics of race as a social construct. Regardless of views of race held by biological and social sciences, race remains a powerful social and political concept throughout the contemporary world.

In racially focused societies it is difficult for most people to accept the idea that race is not an establisher of antithetical sets of persons. It is nonetheless true. To accept the idea requires a greater conscious recognition and tolerance for the complexity and contradictions of life than most people are inclined to make. We all live with these complexities and contradictions but we do it primarily without acknowledging them - often, by denying them, much as I was wont to do with my student's work. That is why political contestations are often so farcical. Candidates and their supporters attack their opponents for being human. We expect people to be what we know they are not and, indeed, cannot be.

People love each other across racial lines. People have friendships across racial lines. People raise children across racial lines. None of this is new. Nor need race alienate people from each other.

To identify as a Black person does not mean that one hates white people, dislikes white people, or is contemptuous of white people. It is easier to conceive of differences in those terms - alienation, hatred, dislike, contempt - but it is 
neither necessary nor practical. People may generally think in such dichotomous terms, but rarely do they live that way. Surely, there are great tensions between women and men. They are different - if in nothing else, in their physiology. Women and men are different, but they don't have to hate each other. They do have to live together. People who differ racially don't have to hate each other, but as a practical matter, they do have to inhabit the same societies. It is therefore important to put aside the equivalence of racial difference with racial animosity. It is important to do that explicitly.

If it is the case that racial differences are not representative of contradictions between people, that people can and do develop close relationships with people of other races, that people can, do, and must live and work with those of other racial groups, then why is it important to assume any racial identity at all? Why is important to have a Black identity? That there are many answers to this question is a marker of its significance. But for this essay, in so much as is possible, I will restrict my consideration to the political dimensions of this question. For political purposes, why is it necessary to assume a Black racial identity? Why do we need a Black movement?

\section{Racial Identity and the Black Movement}

First of all, I must assert that conditions of cross-racial intimacy are far and away the great exception to the physical circumstances of most Black people both in the U.S. and Brazil. That is the deep observation on which both this analysis and the Black movement rest.

Although in the post abolition period in Bahia some Black people escaped oppressive working conditions, most did not. Although some Black people in the U.S. and Brazil have multi-racial families, most do not. Therefore, to characterize a population by a condition of only a small percentage is to lead one deeply astray with respect to the meanings and possibilities of political acts. Most Black people in both the U.S. and Brazil work with other Black people, are friends almost exclusively of other Black people, live in neighborhoods populated primarily by other Black people, and are members of families which are entirely Black. There is no contradiction between their deepest identities.

A related point which has been made by many perceptive analysts with respect to Black people in the U.S. is that it is their racial identity which gives them their greatest political salience, their most effective basis for political education, and the most powerful motive force for political mobilization.

When Black political activity is stripped of racial identity as a central element, it is denied its principal strength, its single most important attribute.

Put another way, the people who are affected most uniformly by those 
conditions which minimize life's possibilities for Black people in the aggregate are robbed of their most effective weapons to struggle against those conditions and to propose new realities when they are denied their racial identity, or when they are denied their racial identity as a legitimate vehicle for political organization and mobilization.

Racial identity is perhaps the most significant element of Black politics in the U.S.

\section{The Black Movement in Brazil}

That is true for the Black movement in Brazil as well. But the Black movement in Brazil is quite different from Black politics in the U.S. The Black movement in the U.S., with respect to its political attributes, is much more comprehensive than the Black movement in Brazil. This is not to associate a higher value with either, but to point to the reality that there are significant differences between them which cannot be wished away.

Kim Butler's sustaining analysis - as well as Jonatas Conceicao's - is that in the Brazilian context, cultural autonomy, cultural resistance, is inherently political. This may well be the case, but to the extent that it is, it is a perception, a conclusion reached by the analyst. It is used to label feelings, thoughts, actions that are not couched in those terms. Many people whose participation in the Brazilian Black movement is self-consciously in the cultural arena, do not see themselves as engaging in politics. Others may observe such cultural activities and label them political, but that is not how many of the participants in these practices characterize themselves.

Others do. In Salvador, lle Aiye and Oludum are perfect cases in point. There are many others. But many cultural organizations do not call themselves political. Many Candomble terreiros, many capoeira schools, many carnaval groups, do not see themselves as political. In Voltaire's terms, they are cultivating their own cabbage patches.

For those Afro-Brazilians who do characterize themselves as political, many do not associate their politics specifically with Black people. They are simply political activists. They are Brazilians. Their politics may be left, right, or center. They may be associated with the trade union movement. Theirs are politics not centered on Black people. Nor do they conceive of such a centering as part of their responsibility. Though this kind of political orientation prevails among Black political figures in Brazil, it is not associated with the Black movement.

Those people whose politics, specifically, can be associated with the Black movement in Brazil tend to constitute a comparatively narrow focus. Most 
of them are associated with the left, particularly the two major leftist parties, though they often are associated with other formations on the left, including the Communist party. Some are deeply involved in the trade union movement. There are exceptions to this generality, but it is accurate to characterize Black movement politics as generally a politics of the left. The Black movement includes few elected or appointed officials. Again, there are exceptions to this tendency, the most notable being Abdias do Nascimento, Benedita da Silva, Paulo Paim, and Luiz Alberto dos Santos. But most elected Black officials don't identify with the Black movement or with any specifically Black-oriented politics, though there are some interesting developments along those lines.

Many people in the Brazilian Black movement are intellectuals, associated with universities, colleges, NGOs, private foundations, and various cultural groups. In no sense can the Black movement be said to constitute a mass movement, or to have a mass base.

Nevertheless, the influence of the Brazilian Black movement far exceeds its numbers or demographic representation. This may well be because of the articulate, focused, and savvy attributes of its participants. Whatever the reason, over the course of 29 years they have changed the very nature and quality of the discourse on race in Brazil. They have made it a significant feature of public life.

\section{The Black Movement in the U.S.}

In the U.S., "Black movement" may be a misnomer, because despite the presence of widespread Black political activity, there is little currently going on that represents a broad-based social movement with generally agreed upon goals. On the other hand, there is a tradition of such movements in the country which still animates much political life.

In addition to the congeries of Civil Rights organizations, hoary with battle flags and legends; the remnants of the Black Power movement and symbols of its victories such as Black Studies programs and the assertion of the right to autonomy in various settings; there are ongoing mobilizations to combat the death penalty, DWB, police brutality, hate crimes, and various manifestations of the contempt in which Black people are generally held by the society at large. The tradition can be drawn on with great effect in every arena from cultural productions - Malcom X - to mass mobilizations - the Million Man March and its progeny. This movement tradition is now deeply imbedded in the culture and is manifested in various ways, but it is not an ongoing social movement.

Currently, Black politics consist of a wide range of activities concerned with influencing power, perceptions, and the quality of life for Black people. The 
U.S. does not really have a political left, but to the extent that it does, that is where Black politics are located. Both mass and elite Black political orientations are far to the left of their compatriots on issues of social responsibility, social justice, and economic egalitarianism. Though social values associated with private behavior tend to be conservative among Black people, those predispositions are not sufficient to override the general liberal tenor of Black people on the role of the state, the public sector, in society. Activities in Black politics include electoral politics; lobbying; public speaking; op-ed pieces, mobilization around specific causes at every level - local, state, national, international; cultural expressions; political education; networking; infrastructure building; and a wide range of selfhelp activities. They also reside in using political office to foster policies which benefit Black people.

In many senses Black political organization is physically less demanding in the U.S. than in Brazil because Black people constitute a much smaller segment of the national population. At around $12 \%$ of the U.S. population there is a much more manageable group to organize than over $50 \%$ of the population as is the case in Brazil. Additionally, the physical infrastructure of the U.S. is much more highly developed than that of Brazil. Infrastructure facilitates organization. The Black population in the U.S., comparatively, has more material resources at its command. This last point, however, should not be exaggerated. Those material resources which Black people in the U.S. have are, for the most part, newly won and still greatly underdeveloped. It is likely a fair assessment that the comparative material resources of the two Black populations were roughly equivalent only fifty years ago.

On the other hand, Black political organization in the United States has always been facilitated by the hegemonic ideology which declared that every one with any African ancestry at all was Black, and that all Black people were the same, subject to the same contempt and despicable treatment at the hands of whites. This ideology was bolstered by the whole system of Jim-Crow terror.

No counterpart for this generation of a collective Black identity has existed in Brazil. Therefore, Black identity is not as salient an element for mobilizing political activity in Brazil as it is in the U.S.

\section{Racial Identity and Black Politics}

While we know that racial identity and the character of racial identity are changing in both countries, it is important to consider the magnitude, the direction, and the likely rates of such changes. Such factors will have tremendous implications for the Black movement in both countries.

Tate, Smith and Seltzer, and Dawson all establish the centrality of Black 
identity as a basis for Black political mobilization and efficacy in the U.S. It is the one advantage Black people have as a group in the U.S. amidst a plethora of disadvantages. Racial identity can be used to mobilize people across class, regional, religious, party, cultural, and at times even language and national origin divides in the U.S. Therefore, a diminution of racial identity speaks to the reduction of the ability of Black people in the aggregate to act concertedly for their common interests. As long as politics, society, and culture operate to lessen life possibilities of all Black people qua Black people, such lessened possibilities have extraordinarily negative effects for Black people.

What is frequently argued is that as life circumstances for Black people change, they will have less in common as Black people and more in common with other sectors of the society who share their status in other respects, e.g., income, education, wealth, occupation, religion, neighborhood, language, national origin.

This supposition might make sense if Black people were isolated individuals. But such a supposition is far from the existential condition. People are linked to families, churches, neighborhoods, friendships, cultural affinities, private associations, all of which, together, override individual considerations. The greater the intensity with which persons are engaged in such relationships and the greater the extent to which those relationships re-enforce each other, the less likely a person's individual status will determine his or her orientation.

For example, I might be a person who doesn't consider himself discriminated against by income because my income might be high; but my mother, brother, aunt, cousin, and best friend might be discriminated on the basis of income because their incomes might be low. In such a situation, I might well support policies which benefit not my situation, but the situations of those to whom I am closely tied. I might consider myself to be free of discrimination based on education because I might have a high level of education; but my father, sister, uncle, and niece might be discriminated against on that basis because they have low levels of education. Again, my policy position might be directed more by the needs of my relatives than my own.

Not only that, but I might prefer to be with members of my church than with other residents of my neighborhood. I might prefer to socialize with people in social organizations I belong to rather than people in my profession. I might, subsequently, identify politically more with my personal acquaintances than with people whose only connection with me is membership in common abstract categories.

In short, we do not live alone as isolated abstractions, but in sets of relationships - and weighted relationships - with other people. These associations effect our political dispositions. This is true even if we remove the variable of disparate racial treatment. 13 
Why do working class Northern Irelanders kill working class Northern Irelanders? Why do Rwandan Hutu farmers kill Rwandan Tutsi farmers? Why do educated Jews in Israel kill educated Muslims in Israel? Clearly, some identities have more substance, resonance, weight, salience, intensity than others.

These factors - present in societies where they are mutually re-enforced - make certain kinds of conceptual, perceptual, and identity change more difficult than others.

It is likely, therefore, that perceptions about race and racial identity will be slow to change among most populations in the U.S. - Black and non-Black. While currently changes in racial perceptions lean towards giving less significance to race than earlier, that tendency is not irreversible. Moreover, change is uneven in all population groups and there is little indication that a sea-change is under way.

In Brazil circumstances are considerably different. There, in so far as a change is abroad with respect to perceptions of race, it is to the effect of recognizing the role that race played and still plays in Brazilian state, society, and culture. This change, however, tends to be most pronounced among intellectuals who study such phenomena, those lay people who are highly informed about racial matters, and in militants of the Black movement.

\section{Conclusions}

The rationale for Black racial identification in the political sphere is twofold: (1) it is as the result of racial categorization in the aggregate that Black people face their greatest obstacles as human beings; (2) racial identity is the single greatest instrument that Black people have for mobilizing and addressing factors that have the greatest common impact on their lives.

With respect to religion, secular beliefs, income, wealth, education, physical location, occupation, culture, Black populations in the U.S. and Brazil are quite heterogeneous. That heterogeneity constitutes a formidable obstacle to common action, one which is mitigated primarily by the unifying effects of shared racial identity. Remove or weaken the racial identity and the efficacy or possibility of efficacious political activity is greatly reduced. In the case of Brazil, racial identity has to overcome threats to its enhancement in order to increase political efficacy.

In both countries there are powerful forces at work tending to the diminution of Black racial identity and political organization on the basis of Black racial identity. Should these forces continue to extend their influence, the possibility for improving the life circumstances of the Black populations at large will be reduced. The Black movement in both countries is critical to maintaining and increasing a 
sense of Black identity. Its adherents, therefore, must focus on developing the most effective ways to achieve that objective.

One step which must be taken in this regard is to popularize the scholarly recognition of the complexity of the human condition - to make plain that it is not only possible but imperative to organize and mobilize to achieve political objectives for Black people without excluding people of other races from our lives, or making them our personal antagonists.

There will always be people in the Black movement who are anti-white. That does not make the movement anti-white any more than a few, Black Brazilian engineers marked the post abolition Afro-Brazilian population as highly educated. We must foster and popularize an appreciation for human complexity. We must articulate explicitly why and how this complexity is an important feature of the Black movement. There are powerful challenges to the continued existence of the Black movement in both the U.S. and Brazil. Left unanswered, those challenges portend a dismal future for African descendants in both countries.

\section{Notes}

* Winant, Howard. "Racial Democracy and Racial Identity: Comparing the U.S. and Brazil." Michael Hanchard (ed.) Racial Politics in Contemporary Brazil. Durham and London: Duke U. Press, 1999.

1. I began my formal study of Black politics in the U.S. as a graduate student in 1967. I have been involved in the Civil Rights Movement, the Black student movement, the Black power movement, and Black politics generally since 1960. I began formal study of Afro-Brazilian politics in 1986 and my friendships with Afro-Brazilian activists date from that year. While much of my academic work on these subjects has not been published, a sample of relevant publications is listed in Sources, below.

2. The classic articulation of this position is found in Oracy Nogueira, Tanto Preto Quanto Branco: Estudos de Relacoes Raciais. Sao Paulo: T. A. Queiroz, Editor, 1985.

3. Edward E. Telles looks specifically at this question, using a microdata sample of the 1980 Brazilian census and the 1979 - 80 National Survey of Black Americans in, "Ethnic Boundaries and Political Mobilization Among Afro-Brazilians: Comparison with the U.S. Case." Michael Hanchard (ed.) Racial Politics in Contemporary Brazil. Durham and London: Duke U. Press, 1999.

4. This point is made most pointedly in Tate, Katherine, From Protest to Politics. NY: Russel Sage Foundation, and Cambridge Mass. and London: Harvard U. Press, 1995; and Dawson, Michael C. Behind the Mule: Race and Class in Afro- 
American Politics. Princeton: Princeton U. Press, 1994.

5. Jonatas Conceicao has stressed this position in conversations and interviews with the writer as well as in his published work. See particularly, "Historia de Lutas Negras: Memorias do Surgimento do Movimento Negro na Bahia," 1978 - 1988: 10 Anos de Luta Contra o Racismo. Salvador, Bahia: Movimento Negro Unificado, 1988.

6. Ile Aiye and Oludum are blocos afros, carnaval groups which deliberately and explicitly take political stances from a self-consciously Black point-of-view.

7. See the important discussion of this point in Ollie A. Johnson, "Racial Representation and Brazilian Politics: Black Members of the National Congress, 1983 1999." Journal of Interamerican Studies and World Affairs, vol. 40, \# 4, Winter, 1998.

8. Interestingly enough, they have developed from a pattern remarkably familiar to Black people within the U.S.: accusations of criminal wrong-doing and prosecutions of Black, elected officials. This propensity is dramatized by the investigation launched against Celso Pitta, the former Black Mayor of Sao Paulo. Black politicians have characterized the moves against Pitta as anti-Black, as racial persecution. A caucus of elected Black politicians from around the country held a press conference on May 22, 2000, to declare, unequivocally, that race plays a significant role in Brazilian politics.

9. See, especially, Dawson, Behind the Mule.

10. Charles Henry conducts an extensive consideration of these relationships in African American Culture and Politics. Bloomington: U. of Indiana Press, 1990.

11. Carlos Hasenbalg and Nelson do Valle Silva make a similar consideration, "Notes on Racial and Political Inequity in Brazil." Hanchard, Racial Politics in Contemporary Brazil, 1999.

12. Tate and Dawson specifically make this case. See note 4 above.

13. Dawson's discussion includes such a perspective. See, particularly his use of a "black utility heuristic," beginning on pp. 10 - 11.

\section{Sources}

Butler, Kim D. Freedoms Given, Freedoms Won: Afro-Brazilians in Post-Abolition Sao Paulo and Salvador. New Brunswick, New Jersey, London: Rutgers U. Press, 1998.

Conceicao, Jonatas. "Historia de Lutas Negras: Memorias do Surgimento do Movimento Negro na Bahia," 1978 - 1988: 10 Anos de Luta Contra o Racismo. Salvador, Bahia: Movimento Negro Unificado, 1988. 
Covin, David. The Unified Black Movement in Brazil, 1978 - 2002, Jefferson, North Carolina, London: McFarland and Company, Inc., Publishers, 2006.

. "Movimento Negro Unificado," Encyclopedia of African-American Culture and History: The Black Experience in the Americas, 2005.

. “A National Black Forum,” The Black Scholar, 2004, vol. 34, \# 3.

. "The Length of Memory: The Black Population and the Presidential Election of 2000," The Black Scholar, June, 2001, vo.. 31, \# 2.

. "In the Eyes of the Beholder: The Brazilian Black Consciousness Movement's Perceptions of Genocide against Afro-Brazilians," in Anatomy of Genocide: State-Sponsored Mass Killings in the 20th Century. Alexandre Kimenyi and Otis Scott (eds). The Edwin Mellen Press, 2001.

."Black Activists During the Ebb Tide of a Social Movement," National Political Science Review, vol. 8, 2000.

. Whither Goeth Black Nationalism: The Case of the MNU in Bahia," National Political Science Review, vol. 7, 1999.

"Narrative, Free Spaces, and Communities of Memory in the Brazilian Black Consciousness Movement," Western Journal of Black Studies. vol. 21,

3 4, Winter, 1997.

. "The Role of Culture in Brazil's Unified Black Movement: Bahia in 1992," Journal of Black Studies, vol. 27, \# 1, Sept, 1996.

"Reflection on Dilemmas in Black Politics," Dilemmas of Black Politics. Georgia Persons (ed). NY: Harper and Collins, 1993.

“Ten Years of the MNU: 1978 - 1988." Journal of Third World Studies, Fall, 1990.

Dawson, Michael C. Behind the Mule: Race and Class in Afro-American Politics. Princeton: Princeton U. Press, 1994.

Hanchard, Michael (ed.) Racial Politics in Contemporary Brazil. Durham and London: Duke U. Press, 1999.

Hasenbalg, Carlos, and Nelson Do Valle Silva, "Notes on Racial and Political In- 
equity in Brazil." Racial Politics in Contemporary Brazil. Michael Hanchard (ed.) Durham and London: Duke U. Press, 1999.

Henry, Charles. Culture and African American Politics. Bloomington: U. of Indiana Press, 1990.

Johnson, Ollie A. "Racial Representation and Brazilian Politics: Black Members of the National Congress, 1983 - 1999." Journal of Interamerican Studies and World Affairs, Vol. 40, \# 4, Winter, 1998.

Nogueira, Oracy. Tanto Preto Quanto Branco: Estudos de Relacoes Raciais. Sao Paulo: T.A. QEIROZ, EDITOR, 1985.

Smith, Robert C. and Robert Seltzer. Race, Class and Culture: A Study in African American Mass Opinion. Albany: State U. Press, 1992.

Tate, Katherine. From Protest to Politics. NY: Russell Sage Foundation, Cambridge, Mass. and London: Harvard U. Press, 1995.

Telles, Edward. "Ethnic Boundaries of Political Mobilization Among Afro-Brazilians: Comparison with the U.S. Case." Racial Politics in Contemporary Brazil. Michael Hanchard (ed.) Durham and London: Duke U. Press, 1999.

Winant, Howard. "Racial Democracy and Racial Identity: Comparing the U.S. and Brazil." Racial Politics in Contemporary Brazil. Michael Hanchard (ed.), Durham and London: Duke U. Press, 1999. 